\title{
Pseudomonas alcaliphila sp. nov., a novel facultatively psychrophilic alkaliphile isolated from seawater
}

\author{
Isao Yumoto, ${ }^{1}$ Koji Yamazaki, ${ }^{2}$ Megumi Hishinuma, ${ }^{1}$ \\ Yoshinobu Nodasaka, ${ }^{3}$ Akio Suemori, ${ }^{4}$ Kenji Nakajima, ${ }^{4}$ Norio Inoue ${ }^{2}$ \\ and Kosei Kawasaki ${ }^{1}$
}

Author for correspondence: Isao Yumoto. Tel: +81 11 8578925. Fax: +81 118578900. e-mail: yumoto@hniri.go.jp

\footnotetext{
1 Bioscience and Chemistry Division, Hokkaido National Industrial Research Institute, Tsukisamu-Higashi, Toyohira-ku, Sapporo 062-8517, Japan

2 Department of Marine Bioresources Chemistry, Faculty of Fisheries, Hokkaido University, Hakodate 041-0821, Japan

3 Laboratory of Electron Microscopy, School of Dentistry, Hokkaido University, Kita-ku, Sapporo 060-8586, Japan

${ }^{4}$ National Institute of Bioscience and HumanTechnology, Higashi 1-1, Tsukuba, Ibaraki 305-8566, Japan
}

\begin{abstract}
Facultatively psychrophilic alkaliphilic strains were isolated from seawater obtained off the coast of Rumoi, Hokkaido, Japan. They were Gram-negative, aerobic straight rods with polar flagella. The isolates were catalase- and oxidase-positive and able to grow at $4{ }^{\circ} \mathrm{C}$, but not at $40{ }^{\circ} \mathrm{C}$. They produced acid from D-glucose under aerobic conditions. The isolates reduced nitrate to nitrite and hydrolysed casein and gelatin, but not starch or DNA. NaCl was required for growth at pH 10 but was not required at neutral pH. The major isoprenoid quinone was ubiquinone-9 (Q-9) and the DNA G+C content was 62.3-63.2 mol\%. The whole-cell fatty acids mainly consisted of $C_{16: 0}, C_{16: 1(9 c)}$ and $C_{18: 1(9 c)}$, with 3$\mathrm{OH} \mathrm{C}_{10: 0}$ and 3-OH $\mathrm{C}_{12: 0}$ as the hydroxyl fatty acids. A larger amount of transunsaturated fatty acid, $\mathrm{C}_{16: 1(9 t)}$ was observed when the cells were grown at pH 7 compared to when cells were grown at pH 10. Phylogenetic analysis based on $16 S$ rRNA gene sequencing indicated that the bacteria are members of the genus Pseudomonas. Analysis of DNA-DNA relatedness data with several close phylogenetic neighbours revealed a low level of hybridization (less than $61 \%$ ). On the basis of phenotypic characteristics, phylogenetic analysis and DNA-DNA relatedness data, it is concluded that these isolates represent a separate new species. Accordingly, the name Pseudomonas alcaliphila is proposed. The type strain is $\operatorname{AL}^{15-21^{\top}}\left(=\mathrm{JCM}^{10630^{\top}}=\right.$ IAM $\left.14884^{\top}\right)$.
\end{abstract}

Keywords: Pseudomonas alcaliphila, alkaliphilic, 16S rRNA, DNA-DNA hybridization, cis/trans unsaturated fatty acids

\section{INTRODUCTION}

There have been many reports concerning microorganisms that are able to grow under extreme environmental conditions such as alkaline and acidic conditions, high and low temperatures and very high pressure under the deep sea (Horikoshi \& Grant, 1991). Such organisms are very important in the fields of biotechnology and for basic research to clarify the physiology for adaptation to extreme environments and to study the genome and biodiversity. A large number of alkaliphiles have been isolated from a variety of environments for industrial applications and for basic research of their physiology and genetics for

The GenBank/EMBL/DDBJ accession number for the $16 \mathrm{~S}$ rRNA sequence of AL15-21 ${ }^{\top}$ is $A B 030583$. adaptation to an alkaline environment. Most of these isolates belong in the genus Bacillus and there are only a few reports on Gram-negative, alkaliphilic microorganisms. To date, more than ten novel species of alkaliphilic Bacillus species have been identified (Nielsen et al., 1995; Fritze, 1996; Yumoto et al., 1998). Although there are several reports on alkaliphilic Pseudomonas strains, these strains have not been identified at the species level (Jones et al., 1998; Kim et al., 1996; $\mathrm{Na}$ et al., 1996). Alkaliphilic strains belonging to genera other than Bacillus and Pseudomonas have also been reported (Horikoshi, 1991; Ikeda et al., 1994). In several alkaliphilic Bacillus strains, the mechanisms of alkaliphily have been studied (Guffanti et al., 1986; Krulwich et al., 1997, 1998). However, it is not known whether this information is applicable in other taxa. Therefore, any new alkaliphilic micro- 
organism not belonging to the genus Bacillus might be a good candidate to study the variation in the mechanisms involved in the adaptation of microorganisms to an alkaline environment.

In this study, facultatively alkaliphilic microorganisms were isolated from seawater obtained off the coast of Rumoi, Hokkaido, Japan. These isolates were examined based on their phenotypic and chemotaxonomic characteristics, and their phylogenetic position and DNA-DNA relatedness in relation to other strains. It was found that the strains should be classified as a new species belonging to the genus Pseudomonas.

\section{METHODS}

Bacterial strains and cultivation. Three strains of alkaliphilic micro-organisms were independently isolated at the same time from the same seawater sample obtained off the coast of Rumoi, Hokkaido, Japan, using PYA (peptone/yeast extract/alkaline) agar medium consisting of $8 \mathrm{~g}$ peptone (Kyokuto), $3 \mathrm{~g}$ yeast extract (Merck), $15 \mathrm{~g}$ agar, $1 \mathrm{~g} \mathrm{~K}_{2} \mathrm{HPO}_{4}, 3.5 \mathrm{mg}$ EDTA, $3 \mathrm{mg} \mathrm{ZnSO}_{4} \cdot 7 \mathrm{H}_{2} \mathrm{O}, 10 \mathrm{mg}$ $\mathrm{FeSO}_{4} \cdot 7 \mathrm{H}_{2} \mathrm{O}, 2 \mathrm{mg} \mathrm{MnSO}_{4} \cdot 4 \mathrm{H}_{2} \mathrm{O}, 1 \mathrm{mg} \mathrm{CuSO} \mathrm{CH}_{4} \cdot 5 \mathrm{H}_{2} \mathrm{O}$, $2 \mathrm{mg} \mathrm{Co}\left(\mathrm{NO}_{3}\right)_{2} \cdot 6 \mathrm{H}_{2} \mathrm{O}$, and $1 \mathrm{mg} \mathrm{H}_{3} \mathrm{BO}_{3}$ in 11 $\mathrm{NaHCO}_{3} / \mathrm{Na}_{2} \mathrm{CO}_{3}$ buffer $(100 \mathrm{mM}$ in deionized water; $\mathrm{pH} 10)$ at $27^{\circ} \mathrm{C}$. Growth at $\mathrm{pH} 7$ was tested in PYA broth containing $100 \mathrm{mM} \mathrm{NaH}{ }_{2} \mathrm{PO}_{4} / \mathrm{Na}_{2} \mathrm{HPO}_{4}$ buffer. Cells for chemotaxonomic analysis were harvested in late exponential phase after cultivation with reciprocal shaking (140 strokes $\min ^{-1}$ ) at $27^{\circ} \mathrm{C}$. In addition to these isolates, Pseudomonas oleovorans MCIMB $6576^{\mathrm{T}}$, Pseudomonas pseudoalcaligenes JCM 5968 ${ }^{\mathrm{T}}$, Pseudomonas nitroreducens JCM 2782 ${ }^{\mathrm{T}}$ and Pseudomonas mendocina JCM 5966 ${ }^{\mathrm{T}}$ were used as reference strains for DNA-DNA relatedness. The micro-organisms were cultivated using nutrient broth containing $5 \mathrm{~g}$ peptone (Kyokuto), $3 \mathrm{~g}$ meat extract (Kyokuto) and $5 \mathrm{~g} \mathrm{NaCl}$ in 11 deionized water, $\mathrm{pH} 7 \cdot 0$ at $25,26,30$ and $37^{\circ} \mathrm{C}$.

Physiological and biochemical characteristics. For the phenotypic characterization, PYA medium was used as the basal medium. The culture was incubated at $27^{\circ} \mathrm{C}$ for 2 weeks and the experiment was performed more than twice unless otherwise stated. Pullulanase and gas production from nitrate were performed according to the methods described by Morgan et al. (1979) and Watahiki et al. (1983), respectively. Determination of substrate utilization as the sole carbon and energy source was performed in US medium containing $0 \cdot 2 \%$ substrate, $2 \mathrm{~g} \mathrm{NH}_{4} \mathrm{Cl}, 2 \mathrm{~g} \mathrm{Na}_{2} \mathrm{HPO}_{4}, 1 \mathrm{~g}$ $\mathrm{KH}_{2} \mathrm{PO}_{4}, 0 \cdot 1 \mathrm{~g} \mathrm{MgSO}_{4} \cdot 7 \mathrm{H}_{2} \mathrm{O}, 0.05 \mathrm{~g} \mathrm{CaCl}_{2} .2 \mathrm{H}_{2} \mathrm{O}$ and $1 \mathrm{ml}$ trace minerals in $11 \mathrm{NaHCO}_{3} / \mathrm{Na}_{2} \mathrm{CO}_{3}$ buffer $(100 \mathrm{mM} ; \mathrm{pH} 10)$. The trace minerals included (per $100 \mathrm{ml})$ $1.8 \mathrm{~g}$ EDTA. $2 \mathrm{Na}, 5.0 \mathrm{~g} \mathrm{ZnSO}{ }_{4} .7 \mathrm{H}_{2} \mathrm{O}, 5.0 \mathrm{~g} \mathrm{FeSO}_{4} .7 \mathrm{H}_{2} \mathrm{O}$, $1.5 \mathrm{~g} \quad \mathrm{MnSO}_{4} .4 \mathrm{H}_{2} \mathrm{O}, 0.4 \mathrm{~g} \quad \mathrm{CuSO}_{4} .5 \mathrm{H}_{2} \mathrm{O}, 0.25 \mathrm{~g} \mathrm{Co}-$ $\left(\mathrm{NO}_{3}\right)_{2} \cdot 6 \mathrm{H}_{2} \mathrm{O}$ and $0 \cdot 1 \mathrm{~g} \mathrm{H}_{3} \mathrm{BO}_{3}$. Other physiological and biochemical characteristics were examined according to the methods of Yumoto et al. (1998) and as described in Cowan \& Steel's Manual (Barrow \& Feltham, 1993).

Electron microscopy. For observation of negatively stained cells under TEM, cells were grown on PYA agar and suspended in physiological saline solution. A small drop of suspension was placed on a carbon-coated copper grid and the cells were negatively stained with $1 \%$ phosphotungstic acid for observation under TEM (model H-800; Hitachi). For SEM, cells were grown on PYA agar and were immersed in a $2 \%$ glutaraldehyde solution in $0 \cdot 1 \mathrm{M}$ cacodylate buffer
$(\mathrm{pH} \mathrm{7.0)}$ for $2 \mathrm{~h}$. After washing three times with $0.1 \mathrm{M}$ cacodylate buffer, they were fixed in $1 \% \mathrm{OsO}_{4}$ for $2 \mathrm{~h}$ and dehydrated in a graduated ethanol series $(50-100 \%)$ and substituted with amyl acetate. The preparations were dried to a critical point in $\mathrm{CO}_{2}$, fixed on a specimen mount and sputter-coated with platinum and palladium. The specimens were observed under SEM (model S-4000; Hitachi) at $3.0 \mathrm{kV}$.

Analysis of isoprenoid quinones. Isoprenoid quinones were extracted by treating $0.5 \mathrm{~g}$ freeze-dried cells with $150 \mathrm{ml}$ chloroform/methanol $(2: 1, \mathrm{v} / \mathrm{v})$ for $2 \mathrm{~h}$ in a reciprocal shaker (120 strokes $\left.\mathrm{min}^{-1}\right)$ at room temperature. The extracted solution was concentrated to dryness and dissolved in acetone. The resulting solution was concentrated, separated by TLC using benzene as the solvent and the isoprenoid quinones were recovered from the TLC plate using acetone. The obtained isoprenoid quinones were analysed using HPLC equipped with a $3.9 \mathrm{~mm} \times 150 \mathrm{~mm}$ Novapak $\mathrm{C}_{18}$ column (Waters); methanol/2-propanol (1:1, $\mathrm{v} / \mathrm{v}$ ) was used as the solvent at room temperature. The HPLC system consisted of a solvent delivery pump (model L-7100; Hitachi) and a spectrophotometric detector (model L-7400; Hitachi) set at $275 \mathrm{~nm}$.

Analysis of whole-cell fatty acids. Whole-cell fatty acids were extracted from $100 \mathrm{mg}$ freeze-dried cells, esterified by acid methanolysis and analysed by GLC equipped with a flameionization detector (model GC 353; GL Sciences) and a $0.25 \mathrm{~mm}$ (i.d.) $\times 100 \mathrm{~m}, \quad 0.2 \mu \mathrm{m}$ film SP-2560 column (Supelco) at an oven temperature of $140^{\circ} \mathrm{C}$ (initially for $15 \mathrm{~min}$ ) increased to $240^{\circ} \mathrm{C}$ at $4{ }^{\circ} \mathrm{C} \mathrm{min}{ }^{-1}$. Fatty acids were identified by comparing them with fatty acid methyl ester standards purchased from Supelco and GL Sciences, and using GC/MS (model INCOS 50; Finnigan mat) connected to a GLC (model 3400; Varian).

DNA base composition and DNA-DNA hybridization. DNA was prepared from bacterial cells according to the method of Marmur (1961). The $\mathrm{G}+\mathrm{C}$ content of the DNA was determined according to the method of Tamaoka \& Komagata (1984). The levels of DNA relatedness were determined fluorometrically by the method of Ezaki et al. (1989) using photobiotin-labelled DNA probes and microplates.

Amplification of 16S rRNA and sequencing. The 16S rRNA gene was amplified by PCR. The sequences of primers used for amplification were 5'-AGAGTTTGATCCTGGCTCAG-3' and 5'-AAGGAGGTGATCCAA/GCCGCA-3', corresponding to positions 8-27 and 1521-1540, respectively, in the 16S rRNA sequence of Escherichia coli (Brosius et al., 1978). The $1.5 \mathrm{~kb}$ PCR product was directly sequenced by the dideoxynucleotide chain-termination method using a DNA sequencer (model 373A; Applied Biosystems). Multiple alignments of the sequence were performed, nucleotide substitution rates $\left(K_{\text {nuc }}\right)$ were calculated and a neighbourjoining phylogenetic tree (Kimura, 1980; Saitou \& Nei, 1987) was constructed using the CLUSTAL W program (Thompson et al., 1994). The similarity values of the sequences were calculated using the GENETYX computer program (Software Development).

\section{RESULTS}

\section{Morphology}

Colonies of strains AL15-21 ${ }^{\mathrm{T}}$, AL15-22 and AL15-2 on PYA agar were circular and colourless; cells were Gram-negative, polarly flagellated straight rods, $0 \cdot 3-$ 

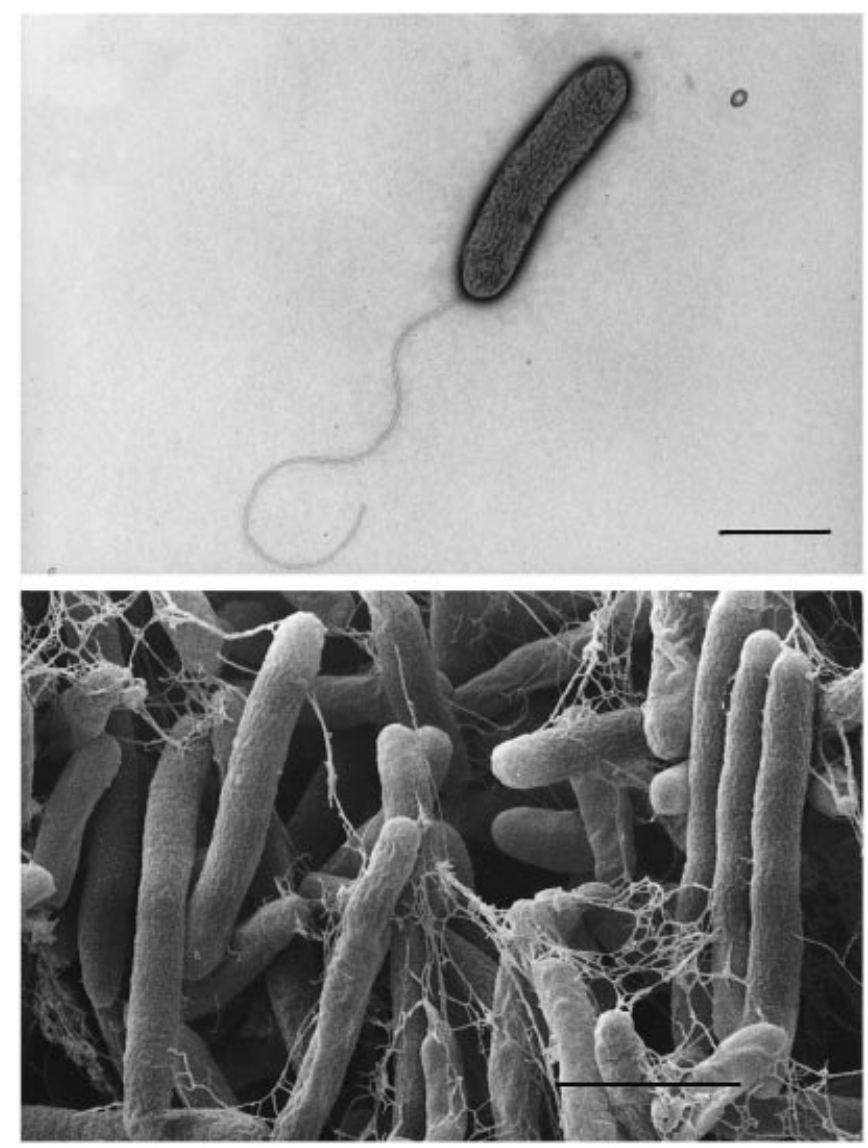

Fig. 1. (top) TEM of a negatively stained cell of $P$. alcaliphila AL15-21 ${ }^{\top}$, showing polar flagellation; bar, $2 \mu \mathrm{m}$. (bottom) SEM of cells of platinum/palladium-coated $P$. alcaliphila AL15-21 ${ }^{\top}$, showing rough surfaces of the cells; bar, $2 \mu \mathrm{m}$.

$0.5 \times 1.5-3.0 \mu \mathrm{m}$ in size (Fig. 1, top). Spore formation was absent and Gram staining was negative. By SEM, a rough surface was observed that was not seen in the reference strains (Fig. 1, bottom).

\section{Phenotypic characteristics}

Physiological and biochemical characteristics of the three isolated strains are listed in Table 1.

\section{Chemotaxonomic characteristics}

The isoprenoid quinones isolated from three isolates using TLC were analysed by HPLC. Analysis revealed that ubiquinone-9 (Q-9) was the predominant isoprenoid quinone in these strains. GLC analysis revealed that the methyl ester derivatives of fatty acids of these strains consisted of $\mathrm{C}_{16: 0}, \mathrm{C}_{16: 1(9 c)}$ and $\mathrm{C}_{18: 1(9 c)}$, with 3-OH $\mathrm{C}_{10: 0}$ and 3-OH $\mathrm{C}_{12: 0}$ as the hydroxyl fatty acids. Among the constituents, $\mathrm{C}_{18: 1(9 \mathrm{c})}$ was the major component, comprising $42 \cdot 7-47 \cdot 5 \%$ of the total fatty acid. The content of trans-unsaturated fatty acid,

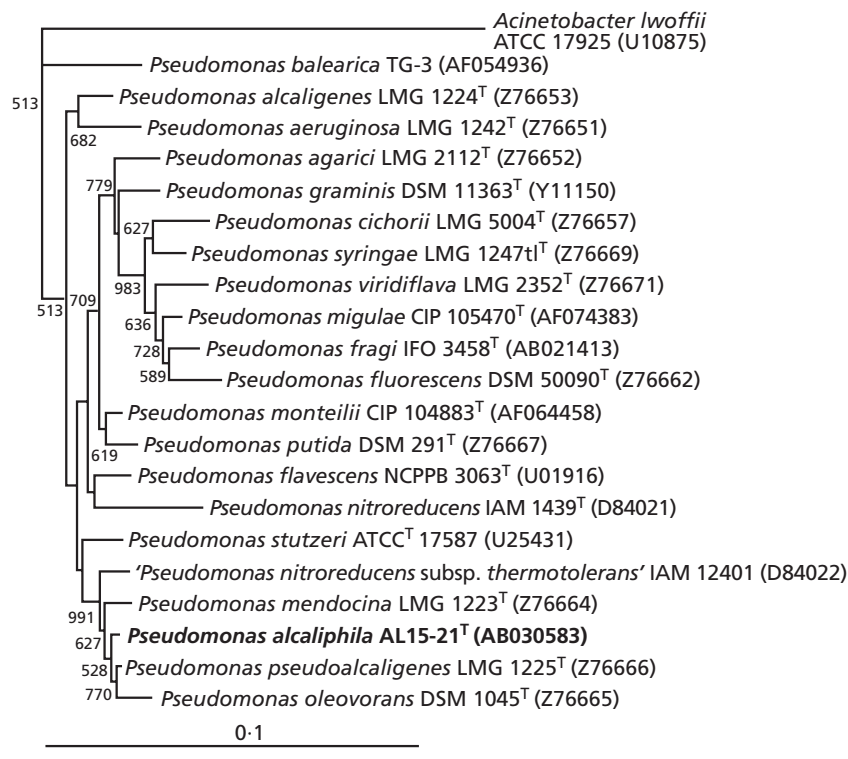

Fig. 2. Phylogenetic tree of Pseudomonas alcaliphila AL15-21 ${ }^{\top}$ and other Pseudomonas strains derived from 16S rRNA gene sequence data, using the neighbour-joining method for calculation. Acinetobacterl woffii was used as the outgroup for the phylogenetic tree. Numbers indicate bootstrap values greater than 500 . Bar, $0 \cdot 1 K_{\text {nuc }}$ unit.

$\mathrm{C}_{16: 1(9 t)}$, was increased when the cells were grown at $\mathrm{pH} 7$ compared to when the cells were grown at $\mathrm{pH} 10$. Results of the analysis of the three isolates are shown in Table 2.

\section{S rRNA gene sequence analysis}

The sequence of 1489 bases of the 16S rRNA gene of strain AL15-21 $1^{\mathrm{T}}$ had $94 \cdot 6-99 \cdot 5 \%$ similarity to the $16 \mathrm{~S}$ rRNA gene sequence of 27 strains of Pseudomonas species. A phylogenetic tree (Fig. 2) constructed by the neighbour-joining method showed that strain AL15$21^{\mathrm{T}}$ belongs to the $P$. mendocina sublineage (Moore et al., 1996) with $99 \cdot 5,98.6,98.6$ and $98.5 \%$ sequence similarities to $P$. pseudoalcaligenes, $P$. oleovorans, $P$. mendocina and ' $P$. nitroreducens subsp. thermotolerans', respectively.

\section{DNA base composition and DNA-DNA hybridization}

The DNA $\mathrm{G}+\mathrm{C}$ contents of strains AL15-21 ${ }^{\mathrm{T}}$, AL15-22 and AL15-2 were 63.2, 63.8 and $62 \cdot 3 \mathrm{~mol} \%$, respectively; these values fall within the definition range of the genus Pseudomonas. According to the results of $16 \mathrm{~S}$ rRNA gene sequence analysis, strain AL15-21 ${ }^{\mathrm{T}}$ was closely related to $P$. oleovorans, $P$. pseudoalcaligenes and P. mendocina. The level of DNA relatedness between strain AL15-21 ${ }^{\mathrm{T}}$, AL15-22 and AL15-2, the three closely related strains given above, and $P$. nitroreducens was estimated (Table 3). DNA relatedness results indicated that the three isolates were tightly related (more than $94 \%$ similarity), but 
Table 1 Phenotypic characteristics of the three strains of Pseudomonas alcaliphila

All tests were performed at $\mathrm{pH} 10$ and $27^{\circ} \mathrm{C}$ except for growth at $\mathrm{pH} 7$ and growth at various temperatures. + , Positive; - , negative; w, weakly positive.

\begin{tabular}{|c|c|}
\hline Character & AL15-21 ${ }^{\mathrm{T}} / \mathrm{AL15}-22 / \mathrm{AL15}-2$ \\
\hline Flagellum & Polar/polar/polar \\
\hline Form & Rods/rods/rods \\
\hline Pigment & White/white/white \\
\hline Gram stain & $-1-1-$ \\
\hline Catalase & $+/+/+$ \\
\hline Oxidase & $+/+/+$ \\
\hline Reduction of $\mathrm{NO}_{3}$ to $\mathrm{NO}_{2}$ & $+/+/+$ \\
\hline Fermentation of glucose & $-1-1-$ \\
\hline \multicolumn{2}{|l|}{ Hydrolysis of: } \\
\hline Casein, gelatin & $+/+/+$ \\
\hline Starch, pullulan, DNA, aesculin & $-1-1-$ \\
\hline Tween $20,40,60,80$ & $+/+1+$ \\
\hline Growth at $\mathrm{pH} 7$ & $+/+1+$ \\
\hline \multicolumn{2}{|l|}{ Growth at $\left({ }^{\circ} \mathrm{C}\right)$ : } \\
\hline $4,10,20,25,30$ & $+/+/+$ \\
\hline 40,50 & $-/-1-$ \\
\hline \multicolumn{2}{|l|}{ Growth in presence of $\mathrm{NaCl}(\%)$ : } \\
\hline 0 & $-/-/-$ \\
\hline 3,5 & $+/+/+$ \\
\hline 7 & $+/-/+$ \\
\hline $9,10,11,12,13,14,15,16,17,18,20$ & $-/-1-$ \\
\hline \multicolumn{2}{|l|}{ Acid produced from: } \\
\hline D-Glucose, D-xylose, mannitol, glycerol, fructose & $+/+/+$ \\
\hline $\begin{array}{l}\text { L-Arabinose, sucrose, sorbitol, raffinose, rhamnose, } \\
\text { myo-inositol, lactose, trehalose, cellobiose, maltose }\end{array}$ & $-1-1-$ \\
\hline Melibiose & $\mathrm{w} /-/-$ \\
\hline D-Galactose & $-/-/ \mathrm{w}$ \\
\hline \multicolumn{2}{|l|}{ Utilization of: } \\
\hline $\begin{array}{l}\text { D-Glucose, mannitol, glycerol, fructose, DL-malic acid, } \\
\text { succinic acid, L-proline, glutamate, L-arginine }\end{array}$ & $+/+/+$ \\
\hline $\begin{array}{l}\text { L-Arabinose, D-xylose, D-mannose, melibiose, sucrose, } \\
\text { sorbitol, raffinose, rhamnose, myo-inositol, D-galactose, lactose, } \\
\text { trehalose, cellobiose, maltose, L-valine }\end{array}$ & $-/-/-$ \\
\hline Glycine & $\mathrm{w} /-/ \mathrm{w}$ \\
\hline
\end{tabular}

these isolates were obviously different $(23 \cdot 2-60 \cdot 6 \%$ similarity) from $P$. oleovorans, $P$. pseudoalcaligenes, $P$. mendocina and P. nitroreducens.

\section{DISCUSSION}

Although the phenotypic characteristics of the three alkaliphilic isolates show a little variation, they can be considered as relatively homogeneous. Furthermore, results of DNA-DNA relatedness between AL15-21 $1^{\mathrm{T}}$ and the other isolates show more than $94 \%$ similarity (Table 3), indeed suggesting that all three isolates belong to the same species.

Phenotypic characteristics and $\mathrm{G}+\mathrm{C}$ contents classified them as Pseudomonas species (Palleroni, 1984). Based on the results of 3-hydroxy fatty acid composition and quinone systems, these isolates belong in
rRNA group I of Palleroni (1984) (Yamada et al., 1982; Oyaizu \& Komagata, 1983). Phylogenetic analysis based on 16S rRNA gene sequence showed that strain AL15-21 ${ }^{\mathrm{T}}$ belongs to the $P$. mendocina sublineage with more than $98 \%$ sequence similarity with the 16S rRNA gene of strains from the same sublineage. DNA-DNA hybridization values of less than $61 \%$ between strain AL15-21 $1^{\mathrm{T}}$ and strains belonging to the $P$. mendocina sublineage showed that the new group differed from the other members in this sublineage. Furthermore, the novel Pseudomonas strains can be differentiated phenotypically from most closely related species, e.g. from Pseudomonas pseudoalcaligenes by the inability to produce acid from D-glucose, hydrolysis of gelatin and Tween 80 , growth at $4{ }^{\circ} \mathrm{C}$, and the ability to grow at $42{ }^{\circ} \mathrm{C}$ (Table 4 ).

It is known that alkaliphilic Bacillus strains possess an 
Table 2 Effect of culture pH on fatty acid composition in Pseudomonas alcaliphila

ND, Not detected.

\begin{tabular}{|c|c|c|c|c|c|c|}
\hline \multirow[t]{2}{*}{ Fatty acid } & \multicolumn{2}{|c|}{ Strain AL15-21 ${ }^{\mathrm{T}}$} & \multicolumn{2}{|c|}{ Strain AL15-22 } & \multicolumn{2}{|c|}{ Strain AL15-2 } \\
\hline & pH 7 & pH 10 & pH 7 & pH 10 & pH 7 & pH 10 \\
\hline $\mathrm{C}_{12: 0}$ & $7 \cdot 8$ & $9 \cdot 3$ & $6 \cdot 6$ & $4 \cdot 0$ & $7 \cdot 4$ & $5 \cdot 0$ \\
\hline $\mathrm{C}_{13: 0}$ & ND & $0 \cdot 5$ & $0 \cdot 1$ & $0 \cdot 2$ & $0 \cdot 2$ & $0 \cdot 3$ \\
\hline $\mathrm{C}_{14: 0}$ & $0 \cdot 5$ & $0 \cdot 3$ & $0 \cdot 3$ & $\mathrm{ND}$ & $0 \cdot 4$ & $0 \cdot 4$ \\
\hline $\mathrm{C}_{14: 1(7 c)}^{14: 0}$ & 0.7 & ND & $0 \cdot 1$ & ND & $0 \cdot 3$ & ND \\
\hline $\mathrm{C}_{15: 0}$ & $0 \cdot 8$ & $2 \cdot 2$ & $0 \cdot 7$ & $1 \cdot 6$ & $0 \cdot 8$ & $2 \cdot 3$ \\
\hline $3-\mathrm{OH} \mathrm{C} \mathrm{C}_{10: 0}$ & $0 \cdot 5$ & 0.5 & $0 \cdot 2$ & $0 \cdot 6$ & $0 \cdot 2$ & $0 \cdot 6$ \\
\hline $\mathrm{C}_{16: 0}$ & $17 \cdot 5$ & $17 \cdot 4$ & $20 \cdot 0$ & $17 \cdot 0$ & $19 \cdot 9$ & $18 \cdot 1$ \\
\hline $\mathrm{C}_{16: 1(9 t)}$ & $3 \cdot 3$ & $0 \cdot 5$ & $3 \cdot 8$ & $0 \cdot 2$ & $3 \cdot 0$ & $0 \cdot 3$ \\
\hline $\mathrm{C}_{16: 1(9 c)}$ & $15 \cdot 7$ & $16 \cdot 6$ & $16 \cdot 9$ & $17 \cdot 5$ & $19 \cdot 3$ & $18 \cdot 4$ \\
\hline $\mathrm{C}_{17: 0}$ & $1 \cdot 0$ & $2 \cdot 7$ & $0 \cdot 8$ & $2 \cdot 4$ & $0 \cdot 7$ & $3 \cdot 5$ \\
\hline $3-\mathrm{OH} \mathrm{C} \mathrm{C}_{12: 0}$ & $1 \cdot 8$ & $3 \cdot 3$ & $1 \cdot 5$ & $4 \cdot 6$ & $1 \cdot 7$ & $4 \cdot 7$ \\
\hline $\mathrm{C}_{18: 0}$ & $1 \cdot 3$ & $0 \cdot 9$ & 0.9 & $0 \cdot 6$ & $1 \cdot 0$ & $0 \cdot 8$ \\
\hline $\mathrm{C}_{18: 1(7 c)}$ & $1 \cdot 0$ & $0 \cdot 3$ & $0 \cdot 9$ & ND & $0 \cdot 6$ & ND \\
\hline $\mathrm{C}_{18: 1(9 c)}^{18: 1(r c)}$ & $45 \cdot 5$ & $42 \cdot 7$ & $45 \cdot 3$ & $47 \cdot 5$ & $43 \cdot 2$ & $42 \cdot 4$ \\
\hline $\mathrm{C}_{18: 1(11 c)}$ & $0 \cdot 5$ & $0 \cdot 9$ & $0 \cdot 4$ & $0 \cdot 5$ & $0 \cdot 5$ & $0 \cdot 5$ \\
\hline Others & $2 \cdot 2$ & $2 \cdot 4$ & $1 \cdot 6$ & $3 \cdot 7$ & $1 \cdot 5$ & $3 \cdot 0$ \\
\hline
\end{tabular}

Table 3 DNA-DNA relatedness among strains examined in this study

Reassociation values are means of 2-4 determinations; statistical analysis was done by Student's $t$-test at $P=0 \cdot 05$. ND, Not determined.

\begin{tabular}{|c|c|c|c|}
\hline \multirow[t]{2}{*}{ Species } & \multirow[t]{2}{*}{ Strain } & \multicolumn{2}{|c|}{ Reassociation (\%) with biotinylated DNA from: } \\
\hline & & P. alcaliphila AL15-2 ${ }^{\mathrm{T}}$ & P. pseudoalcaligenes JCM $5968^{\mathrm{T}}$ \\
\hline P. alcaliphila & AL $15-21^{\mathrm{T}}$ & 100 & $59 \cdot 2 \pm 4 \cdot 4$ \\
\hline P. alcaliphila & AL15-22 & $94 \cdot 3 \pm 2 \cdot 3$ & $60 \cdot 6 \pm 3 \cdot 8$ \\
\hline P. alcaliphila & AL15-2 & $96 \cdot 8 \pm 0 \cdot 9$ & $57 \cdot 7 \pm 1 \cdot 3$ \\
\hline P. pseudoalcaligenes & $\mathrm{JCM} 5968^{\mathrm{T}}$ & $56 \cdot 7 \pm 3 \cdot 6$ & 100 \\
\hline P. mendocina & JCM $5966^{\mathrm{T}}$ & $51 \cdot 1 \pm 1 \cdot 7$ & $57 \cdot 9 \pm 0 \cdot 5$ \\
\hline P. nitroreducens & JCM $2782^{\mathrm{T}}$ & $23 \cdot 2 \pm 2 \cdot 1$ & $24 \cdot 2 \pm 1 \cdot 4$ \\
\hline P. oleovorans & MCIMB $6576^{\mathrm{T}}$ & $51 \cdot 2 \pm 3 \cdot 6$ & ND \\
\hline
\end{tabular}

$\mathrm{Na}^{+} / \mathrm{H}^{+}$antiporter for cytoplasmic $\mathrm{pH}$ regulation (Krulwich et al., 1997). In addition to $\mathrm{Na}^{+}$transport systems, these strains possess also $\mathrm{Na}^{+}$-dependent solute transport and flagellar rotation systems. However, an apparent $\mathrm{Na}^{+}$requirement for growth was not always observed in these micro-organisms because of strain differences in the affinity to $\mathrm{Na}^{+}$(Garcia et al., 1983; Guffanti et al., 1980; Krulwich et al., 1982). On the other hand, the marine bacterium Vibrio alginolyticus possesses an $\mathrm{Na}^{+}$translocating respiratory component which works under alkali conditions, but not under neutral conditions (Tokuda \& Unemoto, 1981, 1982), in addition to the $\mathrm{Na}^{+}$-dependent solute transport (Tokuda et al., 1982) and flagellar rotation systems (Atsumi et al., 1992). In P. alcaliphila, an obvious $\mathrm{Na}^{+}$requirement was recognized when the cells were grown at $\mathrm{pH} 10$ but not when grown at $\mathrm{pH} 7$.
This observation suggests that a different ion-transport system or respiratory system might operate when growing at a different $\mathrm{pH}$.

Recently, trans-unsaturated fatty acids were detected in bacterial lipids as well as the commonly found cisunsaturated fatty acid isomers (Keweloh \& Heipieper, 1996). These membrane lipid constituents had greater concentration in bacterial cells exposed to various environmental stresses, e.g. heat, harmful compounds and high salinity (Heipieper et al., 1996; Loffeld \& Keweloh, 1996; Okuyama et al., 1996). The increase in the amount of trans-unsaturated fatty acid is accompanied by an appropriate decrease in the corresponding cis isomer. cis/trans isomerization of unsaturated fatty acids occurs by direct isomerization of the double bond without a shift of its position. The 
Table 4 Differential characteristics of Pseudomonas alcaliphila and related species

Symbols:,$+ 90 \%$ or more of strains are positive;,$- 90 \%$ or more of strains are negative; \pm , variable or slight reaction; $\mathrm{D}$, reactions differ among strains; ND, no data. All tests for $P$. alcaliphila were performed at $\mathrm{pH} 7$. Characteristics of other Pseudomonas species were cited from Palleroni (1984), Hildebrand et al. (1994), Bennasar et al. (1996), and Kiska \& Gilligan (1999). Strains: 1, Pseudomonas alcaliphila; 2, Pseudomonas pseudoalcaligenes; 3, Pseudomonas oleovorans; 4, Pseudomonas mendocina; 5, Pseudomonas flavescens; 6, Pseudomonas balearica; 7, Pseudomonas stutzeri; 8, Pseudomonas alcaligenes; 9 , Pseudomonas aeruginosa; 10, Pseudomonas putida.

\begin{tabular}{|c|c|c|c|c|c|c|c|c|c|c|}
\hline Characteristic & 1 & 2 & 3 & 4 & 5 & 6 & 7 & 8 & 9 & 10 \\
\hline Acid production from D-glucose & + & - & $-{ }^{*}$ & + & ND & ND & + & - & + & + \\
\hline Nitrate reduction & + & + & ND & + & ND & + & + & $\mathrm{D}$ & + & - \\
\hline Gas from nitrate & - & - & $-*$ & + & - & + & + & - & + & - \\
\hline Arginine dihydrolase & + & $\mathrm{D}$ & ND & + & - & ND & - & $\mathrm{D}$ & + & + \\
\hline Aesculin hydrolysis & - & - & $-*$ & - & ND & ND & - & - & - & - \\
\hline Gelatin hydrolysis & + & - & - & - & + & - & - & - & $\mathrm{D}$ & - \\
\hline Starch hydrolysis & - & - & + & - & - & + & + & - & - & - \\
\hline Tween 80 hydrolysis & + & - & $-*$ & + & - & ND & + & $\mathrm{D}$ & \pm & $\mathrm{D}$ \\
\hline Growth at $4^{\circ} \mathrm{C}$ & + & - & $-*$ & - & ND & ND & - & - & - & $\mathrm{D}$ \\
\hline Growth at $42{ }^{\circ} \mathrm{C}$ & - & + & $+^{*}$ & + & - & + & D & - & + & - \\
\hline DNA G $+\mathrm{C}$ content $(\mathrm{mol} \%)$ & $62 \cdot 3-63 \cdot 2$ & $62-64$ & ND & $62 \cdot 9-64 \cdot 3$ & 63 & $64 \cdot 1-64 \cdot 4$ & $60 \cdot 6-66 \cdot 3$ & 64-68 & $67 \cdot 2$ & $60 \cdot 7-62 \cdot 5$ \\
\hline
\end{tabular}

* Tested in this study using type strain because data is not available from the literature.

conversion of cis-unsaturated fatty acids into transunsaturated fatty acids reduces the membrane fluidity (Diefenback et al., 1992). In the present study, it was observed that the content of trans-unsaturated fatty acid, $\mathrm{C}_{16: 1(9 t)}$, increased when the cells were grown at $\mathrm{pH} 7$ compared with when cells were grown at $\mathrm{pH} 10$. This is the first report of cis/trans isomerization occurring in response to the ambient $\mathrm{pH}$. However, an estimate of membrane fluidity depending on the culture $\mathrm{pH}$ was not tried.

On the basis of the above results, the name Pseudomonas alcaliphila sp. nov. is proposed for this new group of organisms.

\section{Description of Pseudomonas alcaliphila sp. nov.}

Pseudomonas alcaliphila (al.ca.li'phi.la. N.L. adj. alcaliphila alkali-loving).

Cells are Gram-negative straight rods $(0 \cdot 3-0.5 \times 1 \cdot 5-$ $3.0 \mu \mathrm{m})$, motile by means of a single polar flagellum. Colonies are circular and colourless. Catalase- and oxidase-positive. No growth is observed without $\mathrm{NaCl}$ in the medium at $\mathrm{pH} 10$, whereas growth is seen at $\mathrm{pH} 7$ in absence of $\mathrm{NaCl}$. Growth occurs in media supplemented with $3-5 \% \mathrm{NaCl}$, but not in media with salinity higher than $9 \%$ at $\mathrm{pH} 10$. Growth occurs at $4-30{ }^{\circ} \mathrm{C}$, but no growth is observed at $40{ }^{\circ} \mathrm{C}$ or higher. Nitrate is reduced to nitrite. Acid is produced from D-glucose, D-xylose, mannitol, glycerol and fructose when grown at $\mathrm{pH} 10$. No acid is produced from L-arabinose, sucrose, sorbitol, raffinose, rhamnose, myo-inositol, lactose, trehalose, cellobiose or maltose. Hydrolyses casein, gelatin, and Tween 20, 40, 60 and 80 , but not starch, DNA, pullulan or aesculin. Utilizes D-glucose, mannitol, glycerol, fructose, DL-malic acid, succinic acid, L-proline, glutamate and L-arginine, but not L-arabinose, D-xylose, D-mannose, melibiose, sucrose, sorbitol, raffinose, rhamnose, myo-inositol, D-galactose, lactose, trehalose, cellobiose, maltose or $\mathrm{L}$-valine. The major isoprenoid quinone is Q-9. The whole-cell fatty acids contain mainly $\mathrm{C}_{16: 0}, \mathrm{C}_{16: 1(9 \mathrm{c})}$ and $\mathrm{C}_{18: 0}$, with 3-OH $\mathrm{C}_{10: 0}$ and 3-OH $\mathrm{C}_{12: 0}$ as the hydroxyl fatty acids. The DNA $\mathrm{G}+\mathrm{C}$ content is 62.3-63.2 mol\% (determined by HPLC). The type strain, AL15-21 ${ }^{\mathrm{T}}$, has been deposited at The Institute of Physical and Chemical Research (RIKEN), Wako, Japan, and the IAM Culture Collection, University of Tokyo, Tokyo, Japan, as JCM $10630^{\mathrm{T}}$ and IAM $14884^{\mathrm{T}}$, respectively.

\section{REFERENCES}

Atsumi, T., McCarter, L. \& Imae, Y. (1992). Polar and lateral flagellar motors of marine Vibrio are driven by different ionmotive forces. Nature 355, 182-184.

Barrow, G. L. \& Feltham, R. K. A. (1993). Cowan and Steel's Manual for the Identification of Medical Bacteria, 3rd edn. Cambridge: Cambridge University Press.

Bennasar, A., Rosselló-Mora, R., Lalucat, J. \& Moore, E. R. B. (1996). 16S rRNA gene sequence analysis relative to genomovars of Pseudomonas stutzeri and proposal of Pseudomonas balearica sp. nov. Int J Syst Bacteriol 46, 200-205.

Brosius, J., Palmer, J. L., Kennedy, J. P. \& Noller, H. F. (1978). Complete nucleotide sequence of $16 \mathrm{~S}$ ribosomal RNA gene from Escherichia coli. Proc Natl Acad Sci U S A 75, 4801-4805.

Diefenback, R., Heipieper, H. J. \& Keweloh, H. (1992). The conversion of cis- into trans-unsaturated fatty acids in Pseudomonas putida P8: evidence for a role in the regulation of membrane fluidity. Appl Microbiol Biotechnol 38, 382-387. 
Ezaki, T., Hashimoto, Y. \& Yabuuchi, E. (1989). Fluorometric deoxyribonucleic acid-deoxyribonucleic acid hybridization in microdilution wells as an alternative filter genetic among bacterial strains. Int J Syst Bacteriol 39, 224-229.

Fritze, D. (1996). Bacillus haloalkaliphilus sp. nov. Int J Syst Bacteriol 46, 98-101.

Garcia, M. L., Guffanti, A. A. \& Krulwich, T. A. (1983). Characterization of the $\mathrm{Na}^{+} / \mathrm{H}^{+}$antiporter of alkalophilic bacilli in vivo: $\Delta \psi$-dependent ${ }^{22} \mathrm{Na}^{+}$efflux from whole cells. $J$ Bacteriol 156, 1151-1157.

Guffanti, A. A., Blanco, R., Benenson, R. A. \& Krulwich, T. A. (1980). Bioenergetic properties of alkaline-tolerant and alkalophilic strains of Bacillus firmus. J Gen Microbiol 119, 79-86.

Guffanti, A. A., Finkelthal, O., Hicks, D. B., Falk, L., Sidhu, A., Garro, A. \& Krulwich, T. A. (1986). Isolation and characterization of new facultatively alkalophilic strains of Bacillus species. $J$ Bacteriol 167, 766-773.

Heipieper, H. J., Meulenbeld, G., van Oirschot, Q. \& de Bont, J. A. M. (1996). Effect of environmental factors on the trans $/$ cis ratio of unsaturated fatty acids in Pseudomonas putida S12. Appl Environ Microbiol 62, 2773-2777.

Hildebrand, D. C., Palleroni, N. J., Hendson, M., Toth, J. \& Johnson, J. L. (1994). Pseudomonas flavescens sp. nov., isolated from walnut blight cankers. Int J Syst Bacteriol 44, 410-415.

Horikoshi, K. (1991). Microorganisms in Alkaline Environments. Weinheim: Wiley/VCH.

Horikoshi, K. \& Grant, W. D. (1991). Superbugs. Tokyo: Japan Scientific Societies Press.

Ikeda, K., Nakajima, K. \& Yumoto, I. (1994). Isolation and characterization of a novel facultatively alkaliphilic bacterium, Corynebacterium sp., grown on $n$-alkanes. Arch Microbiol 162, 381-386.

Jones, B. E., Grant, W. D., Duckworth, A. W. \& Owenson, G. G. (1998). Microbial diversity of soda lakes. Extremophiles 2, 191-200

Keweloh, H. \& Heipieper, H. J. (1996). Trans unsaturated fatty acids in bacteria. Lipids 31, 129-137.

Kim, E.-S., Na, H.-K., Jhon, D.-Y., Yoo, O. J., Chun, S.-B. \& Wui, I.-S. (1996). Cloning, sequencing and expression of amylase isozyme gene from Pseudomonas sp. KFCC 10818. Biotechnol Lett 18, 169-174.

Kimura, M. (1980). A simple method for estimating evolutionary rates of base substitution through comparative studies of nucleotide sequences. J Mol Evol 16, 111-120.

Kiska, D. L. \& Gilligan, P. H. (1999). Pseudomonas. In Manual of Clinical Microbiology, 7th edn, pp. 517-525. Edited by P. R. Murray, E. J. Baron \& M. A. Pfaller. Washington, DC: American Society for Microbiology.

Krulwich, T. A., Guffanti, A. A., Bornstein, R. F. \& Hoffstein, J. (1982). A sodium requirement for growth, solute transport and $\mathrm{pH}$ homeostasis in Bacillus firmus RAB. J Biol Chem 257, 1885-1889.

Krulwich, T. A., Ito, M., Gilmour, R. \& Guffanti, A. A. (1997). Mechanisms of cytoplasmic $\mathrm{pH}$ regulation in alkaliphilic strains of Bacillus. Extremophiles 1, 163-169.

Krulwich, T. A., Ito, M., Gilmour, R., Hicks, D. B. \& Guffanti, A. A. (1998). Energetics of alkaliphilic Bacillus species: physiology and molecules. Adv Microb Physiol 40, 401-438.

Loffeld, B. \& Keweloh, H. (1996). cis/trans isomerization fatty acids as possible control mechanism of membrane fluidity in Pseudomonas putida P8. Lipids 31, 811-815.
Marmur, J. (1961). A procedure for the isolation of deoxyribonucleic acid from micro-organisms. J Mol Biol 3, 208-218.

Moore, E. R. B., Mau, M., Arnscheidt, A., Böttger, E. C., Hutson, R. A., Collins, M. D., Van De Peer, Y., De Wachter, R. \& Timmis, K. N. (1996). The determination and comparison of the $16 \mathrm{~S}$ rRNA gene sequences of species of the genus Pseudomonas (sensu stricto) and estimation of the natural intragenetic relationship. Syst Appl Microbiol 19, 478-492.

Morgan, F. J., Adams, K. R. \& Priest, F. G. (1979). A cultural method for the detection of pullulan-degrading enzymes in bacteria and its application to the genus Bacillus. J Appl Bacteriol 46, 291-294.

Na, H.-K., Kim, E.-S., Lee, H. B., Yoo, O. J. \& Jhon, D.-Y. (1996). Cloning and nucleotide sequence of the $\alpha$-amylase gene from alkalophilic Pseudomonas sp. KFCC 10818. Mol Cells 6, 203-208.

Nielsen, P., Fritze, D. \& Priest, F. G. (1995). Phenetic diversity of alkaliphilic Bacillus strains: proposal for nine new species. Microbiology 141, 1745-1761.

Okuyama, H., Enari, D., Shibahara, A., Yamamoto, K. \& Morita, N. (1996). Identification of activities that catalyze the cis-trans isomerization of the double bond of a mono-unsaturated fatty acid in Pseudomonas sp. strain E-3. Arch Microbiol 165, 415-417.

Oyaizu, H. \& Komagata, K. (1983). Grouping of Pseudomonas species on the basis of cellular fatty acid composition and the quinone system with special reference of the existence of 3hydroxy fatty acids. J Gen Appl Microbiol 29, 17-40.

Palleroni, N. J. (1984). Genus I. Pseudomonas Migula 1984, $237^{\mathrm{AL}}$ (Nom. cons. Opin. 5, Jud. Comm. 1952, 237). In Bergey's Manual of Systematic Bacteriology, vol. 1, pp. 141-199. Edited by N. R. Krieg \& J. G. Holt. Baltimore: Williams \& Wilkins.

Saitou, N. \& Nei, M. (1987). The neighbor-joining method: a new method for reconstructing phylogenetic trees. Mol Biol Evol 4, 406-425.

Tamaoka, J. \& Komagata, K. (1984). Determination of DNA base composition by reversed-phase high-performance liquid chromatography. FEMS Microbiol Lett 25, 125-128.

Thompson, J. D., Higgins, D. G. \& Gibson, T. J. (1994). CLUSTAL $\mathrm{W}$ : improving the sensitivity of progressive multiple sequence weighing, position-specific gap penalties and weight matrix choice. Nucleic Acids Res 22, 4673-4680.

Tokuda, H. \& Unemoto, T. (1981). A respiration-dependent primary sodium extrusion system functioning at alkaline $\mathrm{pH}$ in the marine bacterium Vibrio alginolyticus. Biochem Biophys Res Commun 102, 265-271.

Tokuda, H. \& Unemoto, T. (1982). Characterization of the respiration-dependent $\mathrm{Na}^{+}$pump in the marine bacterium Vibrio alginolyticus. J Biol Chem 257, 10007-10014.

Tokuda, H., Sugasawa, M. \& Unemoto, T. (1982). Roles of $\mathrm{Na}^{+}$ and $\mathrm{K}^{+}$in alpha-aminoisobutyric acid transport by the marine bacterium Vibrio alginolyticus. J Biol Chem 257, 788-794.

Watahiki, M., Hata, S. \& Aida, T. (1983). $\mathrm{N}_{2} \mathrm{O}$ reduction and inhibition of $\mathrm{N}_{2} \mathrm{O}$ reduction by denitrifying Pseudomonas sp. 220A in the presence of oxygen. Agric Biol Chem 47, 1991-1996.

Yamada, Y., Takinami-Nakamura, H., Tahara, Y., Oyaizu, H. \& Komagata, K. (1982). The ubiquinone system in the strains of Pseudomonas species. J Gen Appl Microbiol 28, 7-22.

Yumoto, I., Yamazaki, K., Sawabe, T., Nakano, K., Kawasaki, K., Ezura, Y. \& Shinano, H. (1998). Bacillus horti sp. nov., a new Gram-negative alkaliphilic bacillus. Int $J$ Syst Bacteriol 48, 1357-1362. 